\title{
TEMPERATURE AND PRESSURE EFFECT ON PERMEABILITY OF CHINESE SANDSTONE: A REVIEW
}

\author{
Zhenlong GE, Qiang SUN * and Wenping LI
}

School of Resources and Geosciences, China University of Mining and Technology, Xuzhou, Jiangsu Province, China

*Corresponding author's e-mail: sunqiang04@126.com

\section{ARTICLE INFO}

Article history:

Received 22 May 2018

Accepted 21 September 2018

Available online 27 September 2018

Keywords:

High temperature

Confining pressure

Permeability

Threshold temperature

\begin{abstract}
Permeability plays an important role in the field of geotechnical engineering. Under high temperature and high pressure condition, the physical-chemical and structure properties (such as decomposition, oxidation, dehydration, evaporation, phase transition etc.) of rock have obviously changing, which are significant affected the rock permeability. In order to analyze the influence of temperature and confining pressure on the permeability of rock (sandstones, siltstones and conglomerates) data for permeability was obtained from the literature. The results indicate that temperature and confining pressure have great influence on the permeability of rock, especially for sandstone. There is a threshold temperature and when the heating temperature is lower than the threshold temperature, the permeability of sandstone gradually increases with an increase in temperature. When the heating temperature is higher than $300{ }^{\circ} \mathrm{C}$ (especially $400{ }^{\circ} \mathrm{C}$ ), the permeability rapidly increases. The permeability of sandstone decreases gradually with the confining pressure increases. This study of the relationship between rock permeability and temperature and confining pressure lays a foundation for investigations of multi-disciplinary issues regarding high temperatures and high pressures and it can be used for the study of petroleum storage and safe nuclear waste disposal.
\end{abstract}

\section{INTRODUCTION}

Permeability is an important physical parameter in the geological sciences and geotechnical engineering and has been investigated with regard to, coal gasification (Hetherington and Thambimuthu, 2003), disposal of high-level radioactive wastes (Takeda et al., 2009), underground oil and gas reservoirs (Shahverdi and Sohrabi, 2017), shale oil production (Egboga et al., 2016), extraction of geothermal energy (Somerton and Boozer, 1960; Zarichyak et al., 2013), protection of stone cultural relics (Hajpál, 2002; Hajpál and Török, 2004), underground oil or gasification (Wu et al., 2003; Kök, 2009; Zhao et al., 2009; Ranjith et al., 2012;), deep petroleum boring (Gao, 2005; Dutton et al., 2012), coal pyrolysis (Zhao et al., 2009; Liang et al., 2005), water inrushes in underground projects (Ding et al., 2016) and extraction of geothermal energy (Yang et al., 2017). In these experiments, the rock is always affected by certain temperatures and confining pressures.

Under high temperature, a series of physical and chemical changes occur in the rock and they have an important influence on rock permeability. Following a high temperature treatment, the changes in the pores and the cracks in the rock are related to the thermal expansion and structural changes in the rock $(\mathrm{Xu}$ et al., 2008 and Qian et al., 2015). The changes in the pores and cracks of the rock are related to the deformation of the rock under different confining pressure. All these changes will affect the rock permeability. The permeability of the rock has an important impact on many engineering activities. For example, in the underground storage of nuclear waste, the decay of radioisotopes generates a large amount of heat, which causes the temperature of the rock mass around the nuclear waste to rise and the rock to be thermally damaged. Cracks and pores inside the rock increase, the permeability increases and radioactive materials penetrate into the groundwater, causing great harm to people's production and life. As for underground oil or gasification storage, high temperature will change the internal structure of the rock: improve the flow passage of the fluid and change the permeability of the rock, which is not good for oil storage.

In this study, we assembled a large amount of experimental data and developed charts based on these data. By analyzing the changes in the data, we can observe the changes in the permeability of sandstone and conglomerates under different temperatures and confining pressures. Although the specimen size is not uniform in the experiment (Table 1), it has no significant effect on the measurement of permeability. The remainder of this paper is organized as follows: in Section 2, we present 
Table 1 Characteristics of the reviewed sandy rock.

\begin{tabular}{|c|c|c|c|c|c|c|c|c|}
\hline Type & Rock type & Ref. & Site & $\begin{array}{l}\text { Main } \\
\text { mineral }\end{array}$ & Sample size & $\begin{array}{c}\text { Sample } \\
\text { Size }(\mathrm{mm})\end{array}$ & $\begin{array}{c}\text { Test } \\
\text { equipment }\end{array}$ & Test process \\
\hline Permeability & Sandstone-1 & $\begin{array}{c}\text { You and } \\
\text { Kang. (2009) }\end{array}$ & Sichuan, China & - & 1 & $25.0 \times 32.5$ & SCMS-B permeability test machine & keep $1 \mathrm{~h}$ \\
\hline Permeability & Sandstone- 2 & $\begin{array}{c}\text { You and } \\
\text { Kang. (2009) }\end{array}$ & Sichuan, China & - & 1 & $24.8 \times 52.7$ & SCMS-B permeability test machine & keep $1 \mathrm{~h}$ \\
\hline Permeability & Sandstone-3 & $\begin{array}{l}\text { You and } \\
\text { Kang. (2009) }\end{array}$ & Sichuan, China & - & 1 & $25.1 \times 46.5$ & SCMS-B permeability test machine & keep $1 \mathrm{~h}$ \\
\hline Permeability & Sandstone-4 & $\begin{array}{c}\text { You and } \\
\text { Kang. (2009) }\end{array}$ & Sichuan, China & - & 1 & $25.1 \times 48.6$ & SCMS-B permeability test machine & keep $1 \mathrm{~h}$ \\
\hline Permeability & Sandstone-5 & $\begin{array}{l}\text { You and } \\
\text { Kang. (2009) }\end{array}$ & Sichuan, China & - & 1 & $24.7 \times 53.1$ & SCMS-B permeability test machine & keep $1 \mathrm{~h}$ \\
\hline Permeability & Siltstone & $\begin{array}{l}\text { Liu et al. } \\
\text { (2001) }\end{array}$ & $\begin{array}{c}\text { Dongying, } \\
\text { Shandong, China }\end{array}$ & - & 4 & $25 \times 50$ & Core permeability measuring device & keep $2 \mathrm{~h}, 0.1 \mathrm{MPa}$ \\
\hline Permeability & conglomerate & $\begin{array}{l}\text { Liu et al. } \\
\text { (2001) }\end{array}$ & $\begin{array}{c}\text { Dongying, } \\
\text { Shandong, China }\end{array}$ & - & 4 & $25 \times 50$ & Core permeability measuring device & keep $2 \mathrm{~h}, 0.1 \mathrm{MPa}$ \\
\hline Permeability & Siltstone & Gao (2004) & Liaoning, China & - & 5 & $5 \times 5 \times 10$ & Core permeability measuring device & $25^{\circ} \mathrm{C}, 3.0 \mathrm{MPa}$ \\
\hline Permeability & conglomerate & Gao (2004) & Liaoning, China & - & 5 & $5 \times 5 \times 10$ & Core permeability measuring device & keep $2 \mathrm{~h}, 0.1 \mathrm{MPa}$ \\
\hline Permeability & Sandstone & $\begin{array}{l}\text { Zhang. } \\
\text { (2015) }\end{array}$ & China & $\begin{array}{c}\text { Feldspar } \\
\text { Quartz } \\
\text { Kaoninite } \\
\text { Chlorite } \\
\text { Illite } \\
\end{array}$ & 4 & $25 \times 50$ & $\begin{array}{l}\text { TAW-1000 type deepwater gap pressure servo } \\
\text { experimental system }\end{array}$ & $\begin{array}{c}10^{\circ} \mathrm{C} / \mathrm{min}, \text { keep } 4 \mathrm{~h}, 5 \mathrm{MPa}, 10 \mathrm{MPa}, \\
20 \mathrm{MPa}, \mathrm{N}_{2}\end{array}$ \\
\hline Permeability & Sandstone & $\begin{array}{l}\text { Liang et al. } \\
\text { (2005) }\end{array}$ & $\begin{array}{l}\text { Fuxin, Liaoning, } \\
\text { China }\end{array}$ & - & 4 & $25 \times 50$ & Gas permeameter & $0.1 \mathrm{MPa}$, keep $3 \mathrm{~h}$ \\
\hline Permeability & Sandstone & $\begin{array}{l}\text { Ding et al. } \\
\text { (2016) }\end{array}$ & $\begin{array}{l}\text { Shuozhou, Shanxi, } \\
\text { China }\end{array}$ & $\begin{array}{c}\text { Feldspar } \\
\text { Siderite } \\
\text { Kaolinite } \\
\text { Illite } \\
\text { Chlorite } \\
\text { Calcite } \\
\text { Siderite }\end{array}$ & 21 & $50 \times 100$ & MTS815.02 and a self-made water fiow device & $20^{\circ} \mathrm{C} / \mathrm{min}$, keep $2 \mathrm{~h}, 8 \mathrm{MPa}$ \\
\hline Permeability & Sandstone & $\begin{array}{l}\text { Yang et al. } \\
\text { (2017) }\end{array}$ & $\begin{array}{c}\text { Rizhao, } \\
\text { Shangdong, Chian }\end{array}$ & - & 36 & $50 \times 100$ & Servo-controlled triaxial equipment & $\begin{array}{c}5^{\circ} \mathrm{C} / \mathrm{min}, \text { keep 2h, } 5 \mathrm{MPa}, 10 \mathrm{MPa}, \\
20 \mathrm{MPa}, 30 \mathrm{MPa}\end{array}$ \\
\hline Permeability & $\begin{array}{c}\text { Fractured } \\
\text { sandstone(MP) }\end{array}$ & $\begin{array}{l}\text { Guo et al. } \\
(2017)\end{array}$ & $\begin{array}{l}\text { Chendu, } \\
\text { China(2017) }\end{array}$ & - & 5 & $25.2 \times 40.4$ & Soap film flow meter & $\begin{array}{l}\text { keep } 2 \mathrm{~h}, 5,10,15,20,25,30,35 \text {, } \\
40,45,50 \mathrm{MPa}, 20^{\circ} \mathrm{C} \sim 100^{\circ} \mathrm{C}, \mathrm{N}_{2}\end{array}$ \\
\hline Permeability & Fractured shale(MP) & $\begin{array}{l}\text { Guo et al. } \\
\text { (2017) }\end{array}$ & $\begin{array}{c}\text { Chendu, } \\
\text { China(2017) }\end{array}$ & - & 5 & $25.3 \times 41.3$ & Soap film flow meter & $\begin{array}{c}\text { keep } 2 \mathrm{~h}, 5,10,15,20,25,30,35, \\
40,45,50 \mathrm{MPa}, 20^{\circ} \mathrm{C} \sim 100^{\circ} \mathrm{C} \mathrm{N}_{2}\end{array}$ \\
\hline Permeability & $\begin{array}{c}\text { Unfractured } \\
\text { sandstone(LP) }\end{array}$ & $\begin{array}{l}\text { Guo et al. } \\
\text { (2017) }\end{array}$ & $\begin{array}{c}\text { Chendu, } \\
\text { China(2017) }\end{array}$ & - & 5 & $25.0 \times 50.3$ & Soap film flow meter & $\begin{array}{c}\text { keep } 2 \mathrm{~h}, 5,10,15,20,25,30,35, \\
40,45,50 \mathrm{MPa}, 20^{\circ} \mathrm{C} \sim 100^{\circ} \mathrm{C} \mathrm{N} \mathrm{N}_{2}\end{array}$ \\
\hline Permeability & $\begin{array}{c}\text { Unfractured } \\
\text { sandstone(ultra-LP) }\end{array}$ & $\begin{array}{l}\text { Guo et al. } \\
\text { (2017) }\end{array}$ & $\begin{array}{c}\text { Chendu, } \\
\text { China(2017) }\end{array}$ & - & 5 & $25.3 \times 50.8$ & Soap film flow meter & $\begin{array}{c}\text { keep } 2 \mathrm{~h}, 5,10,15,20,25,30,35 \text {, } \\
40,45,50 \mathrm{MPa}, 20^{\circ} \mathrm{C} \sim 100^{\circ} \mathrm{C} \mathrm{N} \mathrm{N}_{2}\end{array}$ \\
\hline Permeability & Sandstone(ultra-LP) & $\begin{array}{l}\text { Guo et al. } \\
\text { (2017) }\end{array}$ & $\begin{array}{c}\text { Chendu, } \\
\text { China(2017) }\end{array}$ & - & 5 & $25 \times 50$ & Gas permeability meter & keep $3 \mathrm{~h}, 100 \sim 800^{\circ} \mathrm{C}$ \\
\hline Permeability & Siltstone(ultra-LP) & $\begin{array}{l}\text { Guo et al. } \\
\text { (2017) }\end{array}$ & $\begin{array}{c}\text { Chendu, } \\
\text { China(2017) }\end{array}$ & - & 5 & $25 \times 50$ & Gas permeability meter & keep $3 \mathrm{~h}, \quad 100 \sim 800^{\circ} \mathrm{C}$ \\
\hline Porosity & Sandstone & $\begin{array}{l}\text { Sun et al } \\
(2016)\end{array}$ & $\begin{array}{l}\text { Linyi, Shangdong, } \\
\text { China }\end{array}$ & $\begin{array}{l}\text { Fuldspar } \\
\text { Dolomite } \\
\text { ankerite }\end{array}$ & 40 & $50 \times 100$ & $\begin{array}{l}\text { microporosity structure analyzer apparatus (type } \\
9310 \text { ) }\end{array}$ & $30^{\circ} \mathrm{C} / \mathrm{min}$, keep $30 \mathrm{~min}$ \\
\hline
\end{tabular}




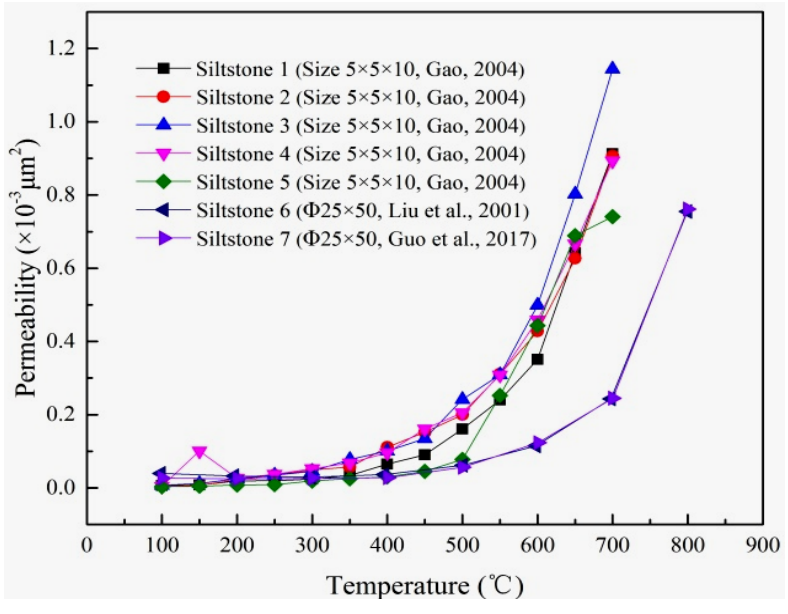

(a)

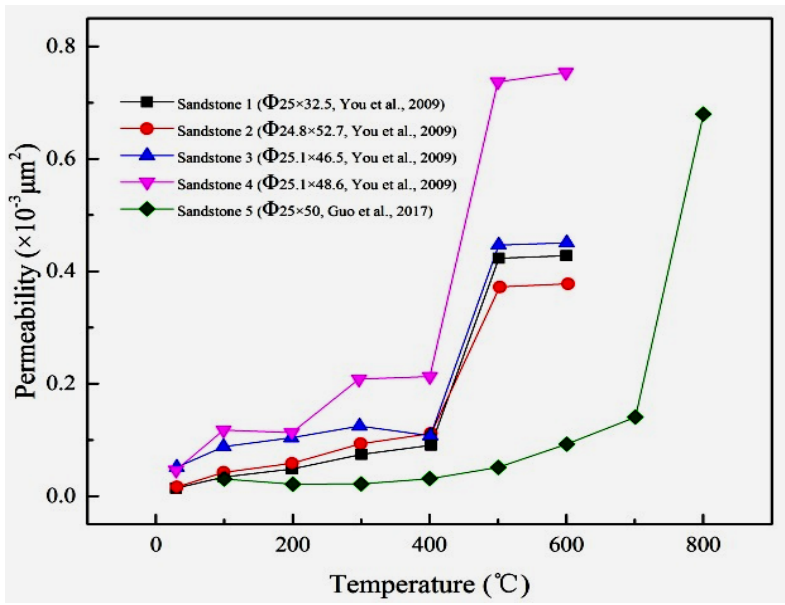

(b)

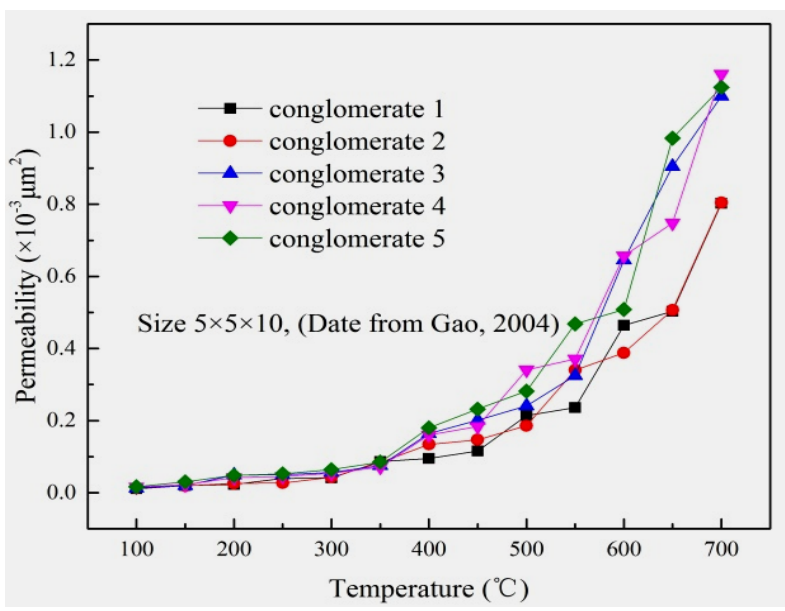

(c)

Fig. 1 Influence of high temperature on the permeability of (a) siltstones, (b) sandstones and (c) conglomerates. experimental data from different researchers. Section 3 describes our reanalysis of the existing experimental data. For further validation, the changes in permeability were analyzed by heating and pressurization. The discussions are presented in Section 4 and Section 5 presents the conclusions.

\section{COLLECTION OF EXPERIMENTAL RESULTS FROM PREVIOUS STUDIES}

In past experiments, the physical and chemical properties of rocks under different conditions were studied by heating and pressing the rocks to determine the permeability, porosity, thermal conductivity of rocks, etc. Each study presents its own unique and novel conclusions. However, because each study has limited experimental data obtained from a small number of rock specimens, some researchers may focus extensively on the subtle differences of a specific rock type while ignoring important common characteristics. For this reason, we integrate data from different sources and derive a number of previously overlooked conclusions using a new perspective.

\section{ANALYSIS AND DISCUSSION 3.1. INFLUENCE OF TEMPERATURE}

Figure 1 shows that the permeability of sandstones, siltstones and conglomerates increases with an increase in the temperature; the change in the permeability indicates that a threshold temperature exists (the temperature at which the rate of increase in permeability increases considerably). When the heating temperature is lower than the threshold temperature, the rate of change in permeability is small and the slope of the curve is gentle; when the temperature is higher than the threshold temperature, the rate of change in permeability increases sharply and the curve becomes steeper. Different types of rocks have different threshold temperatures and the same rock is also different from different regions. Figure 1 shows that the permeability of sandstone, siltstones and conglomerates increases slowly when the heating temperature is lower than $400{ }^{\circ} \mathrm{C}$; when the heating temperature is higher than $400{ }^{\circ} \mathrm{C}$, the permeability increases sharply. The threshold temperature of sandstones, siltstones and conglomerates is between $400{ }^{\circ} \mathrm{C}$ and $600{ }^{\circ} \mathrm{C}$.

\subsection{INFLUENCE OF CONFINING PRESSURE}

Figure 2 shows that the changes of sandstone permeability with confining pressure at different heating temperatures. Figure 2(a) shows the data of initial permeability of sandstone after heat treatment. Figure 2(b) and (c) shows the variation of the elastic modulus $(E)$ of sandstone and the volume expansion ratio of three typical sandstones (Bandera, Berea and Boise). Under the same treatment temperature, the initial permeability generally decreases as the confining pressure increases. When the treatment temperature is higher than $400{ }^{\circ} \mathrm{C}$, as shown by 


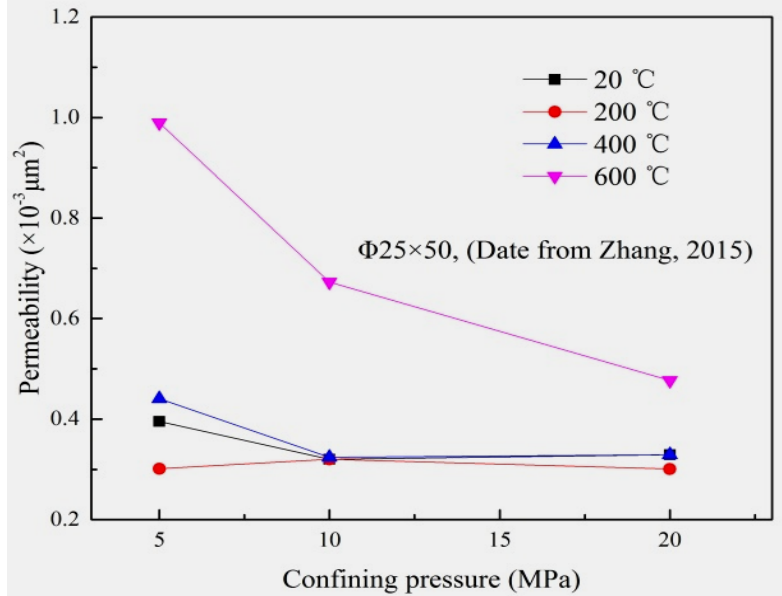

(a)

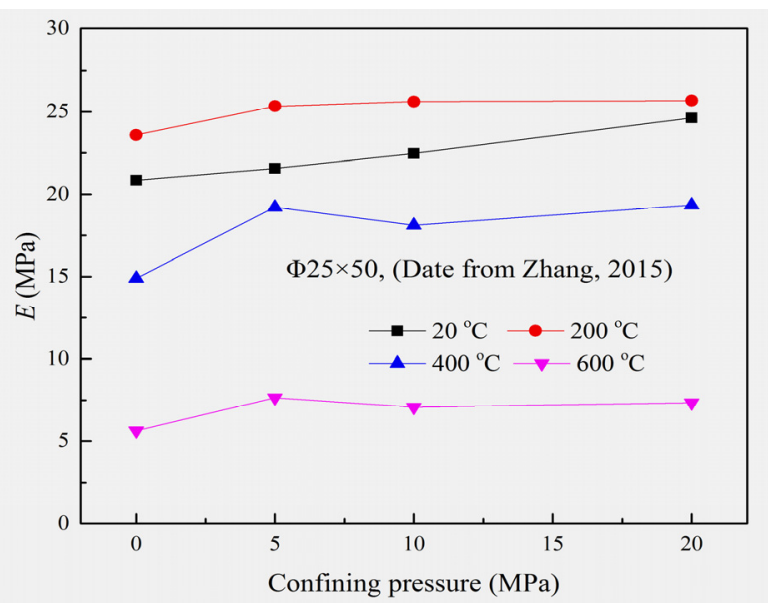

(c)

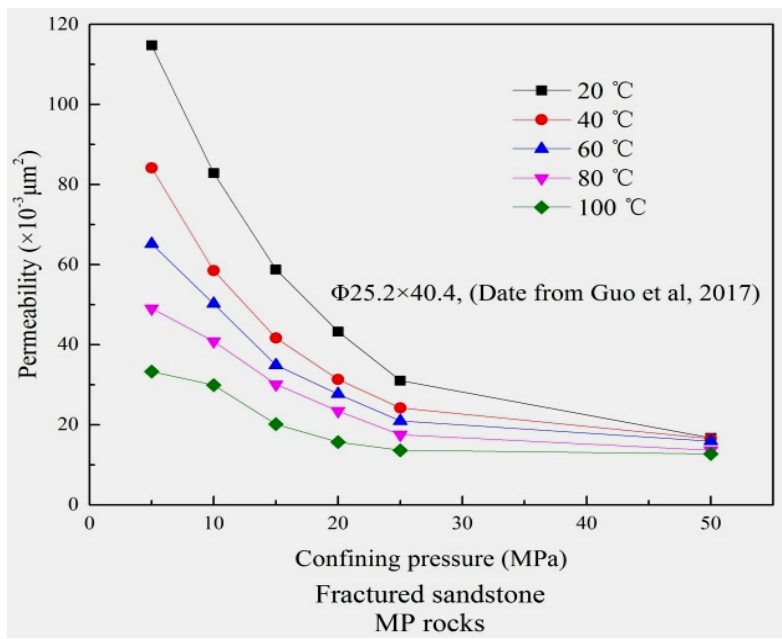

(e)

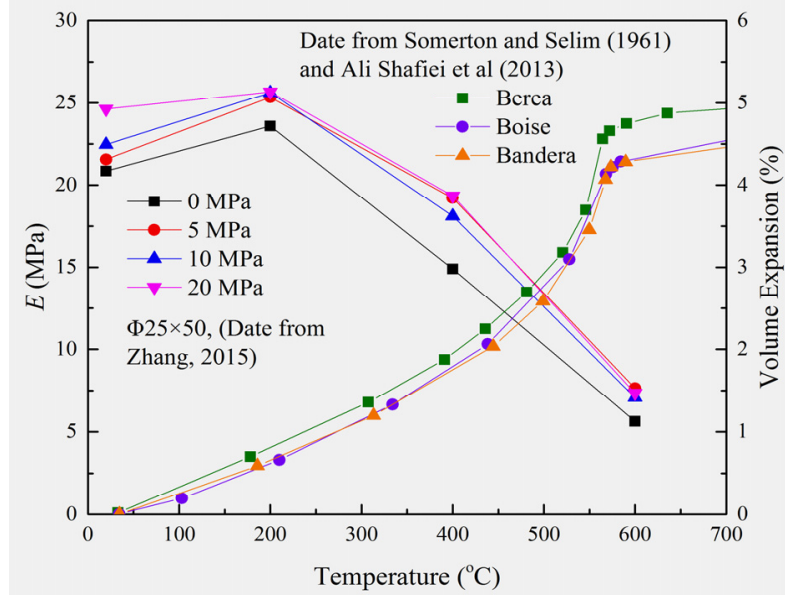

(b)

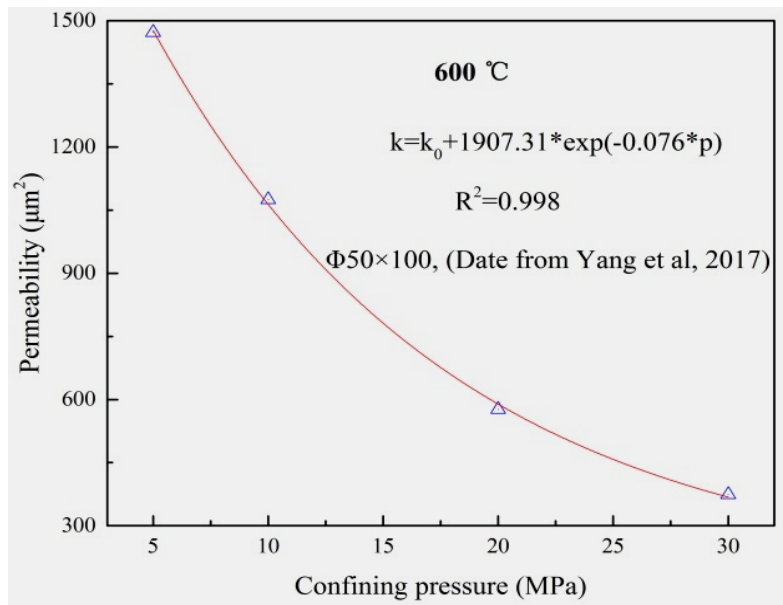

(d)

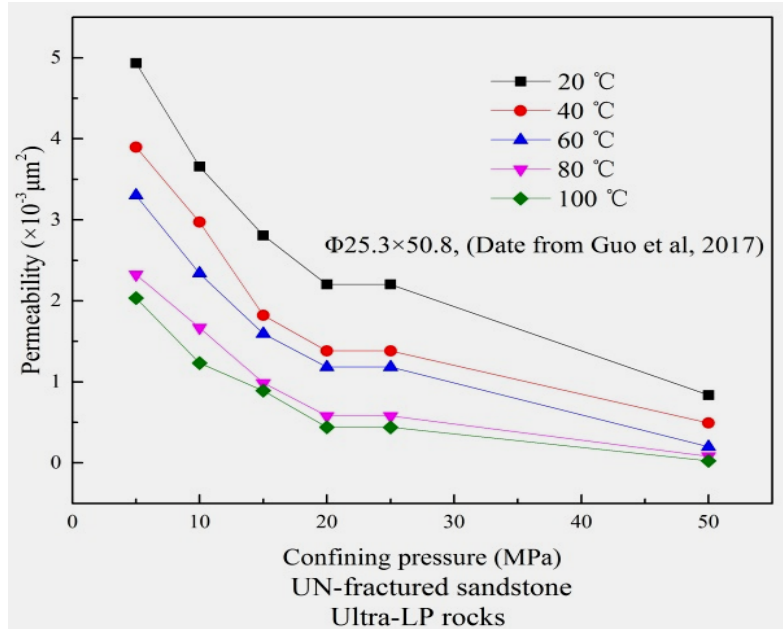

(f)

Fig. 2 Influence of temperature and confining pressure on the permeability of sandstone. 




(a)

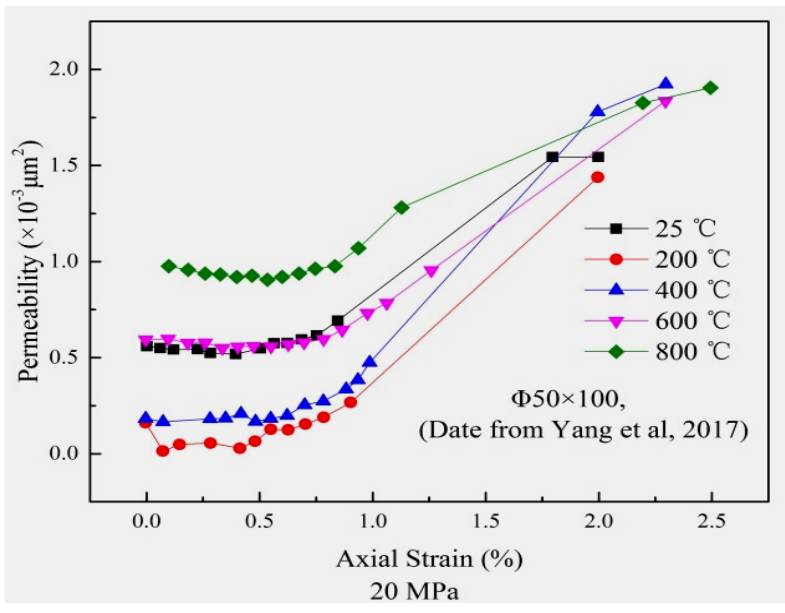

(b)

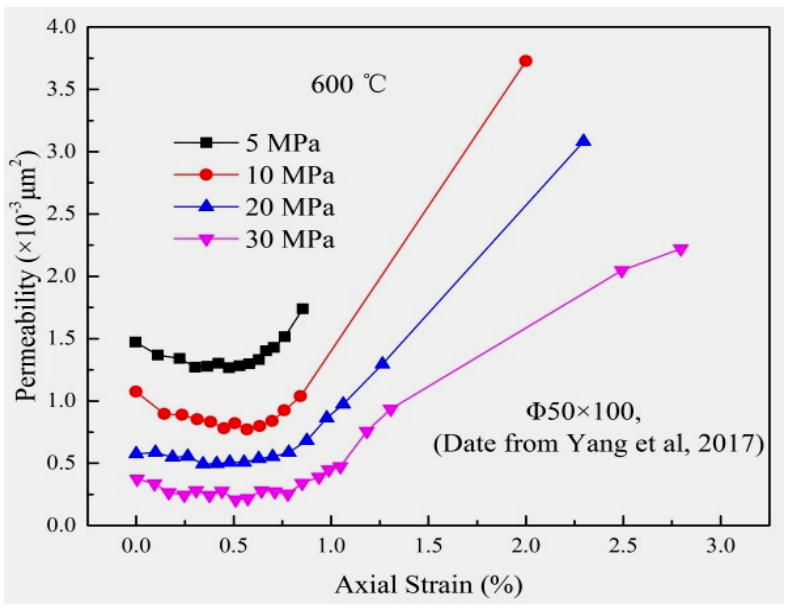

(c)

Fig. 3 Changes in permeability of sandstone with changes in axial strain.
Figure 2(b) and Figure 2(c), the porosity (pores and cracks) of sandstone has a nonlinear increase, which results in the quick increasing of permeability, while the elastic modulus of the sandstone reduces significantly. Therefore, with the increasing of confining pressure, the compressibility of sandstone increases and the permeability decreases, especially when confining pressure is less than $10 \mathrm{MPa}$.

Figure 2(b) and (c) show that the elastic modulus of sandstone increases slowly with temperature at first and then decreases rapidly. When the heat treatment temperature is about $600{ }^{\circ} \mathrm{C}$, the volume of the sandstone is rapidly expanded and the modulus of elasticity is small. This means that the damage inside the rock caused by heating is irreversible (Shafiei and Dusseault, 2013). Figure 2(d) shows the correlation between confining pressure and permeability of sandstone at $600{ }^{\circ} \mathrm{C}$. It can be seen that as the confining pressure increases, the permeability of sandstone decreases significantly. When the confining pressure increases to a certain level, the permeability begins to decrease slowly.

Figure 2(e) and (f) show that the permeability of sandstone decreases with an increase in the confining pressure when the heating temperature is lower than $100{ }^{\circ} \mathrm{C}$. For medium-permeability (MP) fractured sandstone and ultra-low-permeability (ultra-LP) unfractured sandstone, the permeability decreases sharply with the increasing confining pressure when the confining pressure is less than $25 \mathrm{MPa}$; when the confining pressure is greater than $25 \mathrm{MPa}$, the permeability decreases more slowly. The above results show that when the confining pressure is low, the permeability of sandstone decreases exponentially with the increase of confining pressure. When the confining pressure increases to a certain level, it begins to slow down and there is a mutation process.

Figure 3 shows the changes in the permeability of sandstone under different temperatures and different confining pressures during conventional triaxial compression. Figure 3(a) shows that, for different heating temperature of sandstone specimens, when the confining pressure is constant, the permeability of sandstone decreases slowly with the increase of axial strain in triaxial compression and axial strain increases to a certain extent, the permeability increases rapidly. When the heating temperature is greater than $400{ }^{\circ} \mathrm{C}$, the permeability changed suddenly. Figure $3(\mathrm{~b})$ shows that as the thermal treatment temperature increases from $25^{\circ} \mathrm{C}$ to $800{ }^{\circ} \mathrm{C}$, the initial permeability decreases in the range of $25{ }^{\circ} \mathrm{C}$ to $400{ }^{\circ} \mathrm{C}$ and subsequently increases by approximately one order of magnitude. For the sandstone specimens with the same heating temperature, at the initial stage of triaxial compression, the permeability of sandstone decreases with the increase of strain. When the strain reaches a certain stage, the permeability of sandstone increases rapidly. Under the same heat treatment temperature, the permeability of sandstone decreases with the increase of confining pressure (Fig. 3(c)). 


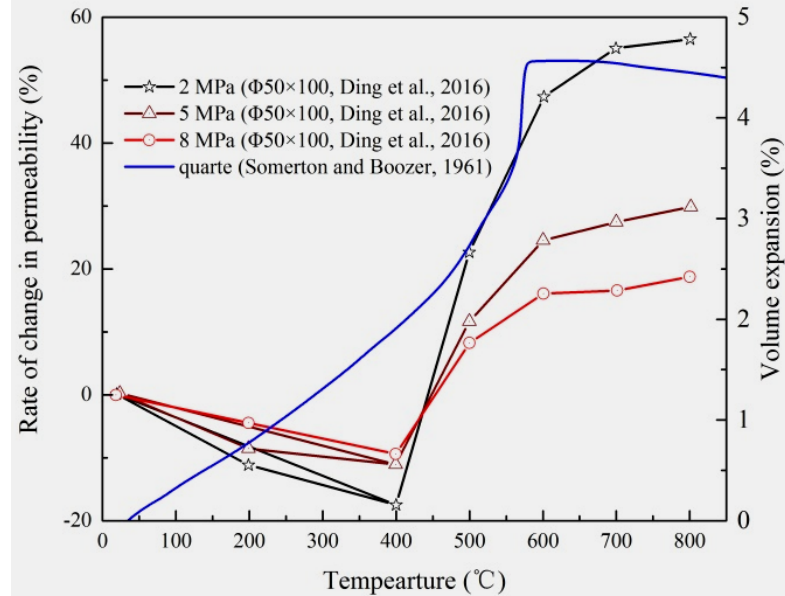

Fig. 4 Rate of change for sandstone permeability and quartz volume due to temperature changes.

\section{DISCUSSIONS}

The rock's internal structure and the stress distribution reach a relatively stable state of equilibrium after diagenesis. When external factors such as temperature and confining pressure change, the balance changes together with physical parameters change,thus affects the rock's permeability.

1. When the heating temperature is lower than the threshold temperature, the main change in the rock specimen is the change in the amount of adsorbed water and interlayer water. The water mainly exists in very small gaps in the rock and gradually evaporates as the temperature increases; therefore, this effect has little influence on the rock permeability. When the heating temperature is higher than the threshold temperature, the water in the rock channel evaporates improving the rock permeability. Moreover, between 300 to $400{ }^{\circ} \mathrm{C}$, the water reaches its critical temperature (i.e. $374^{\circ} \mathrm{C}$ ) (Zhang et al., 2007), at which the water may turn into supercritical fluid, causing changes in the rock internal stress and increase the rock thermal damage.The high temperature also changes the thermal stress in the rock and changes the rock structure, which produces many small cracks inside the rock and enhances the flow capacity of the fluid, thus increasing the rock permeability. Some minerals such as quartz facilitate decomposition and volatilization (such as dehydroxylation of clay minerals) in the process of losing structural water, which may cause an increase in the pores and fractures. When the heating temperature is greater than $600{ }^{\circ} \mathrm{C}$ (Fig. 4), the oxidation-decomposition reaction is strong and the $\alpha$-quartz transforms into $\beta$-quartz and quartz volume dramatic expansion caused structural damage within sandstone, which increases the porosity and permeability.



Fig. 5 Variation in the porosity of sandstone after different treated temperature.

2. During the initial stage of compression, internal fractures are closed and the porosity decreases under deviatoric stress, leading to decreased permeability. As the fractures close, the rock enters the elastic deformation stage. At this stage, the internal structure of the rock is relatively stable and new fractures are not formed; therefore, the permeability change rarely. As the strain increases, new fissures occur in the rock and the internal fissures are reopened and expand, thereby increasing the permeability. When the strain reaches a certain stage, the fissures in the rock expand and connect in a random fashion, which results in a rapid increase the effective porosity and the permeability.

3. Because of differences in the rock composition, the internal structure and the degree of cementation between mineral particles, different rocks have different threshold temperatures. The porosity of the rock is closely related to defects. As the number of defects increases, the quartz volume expands rapidly resulting in a sudden change in the permeability of sandstone (Popp and Kern, 1993; Bai et al., 2002). When the heating temperature is lower than $400{ }^{\circ} \mathrm{C}$, the porosity changes very little, but when the temperature is higher than $400{ }^{\circ} \mathrm{C}$, it begins to increase significantly, resulting in an increase in permeability (Fig. 5). The effects of thermal effect on the permeability are: (a) increased interconnectivity between pre-existing and newly formed cracks or pore, (b) new-microcracks provide additional flow paths and (c) widening of crack aperture reduces impedance to fluid flow resulting from boundary friction. The first two effects are expected to be more important at the lower thermal-cycle temperatures, whereas crack widening is expected to dominate at the higher temperatures (Bauer and Johnson, 1979). 


\section{CONCLUSIONS}

Through the study, we find that temperature and confining pressure have great influence on the permeability of rock. The main conclusions are as follows:

1. Rock permeability increases rapidly at temperatures higher than $300{ }^{\circ} \mathrm{C}$ (especially $400{ }^{\circ} \mathrm{C}$ ). The threshold temperature of sandstones, conglomerates and siltstones is between $400{ }^{\circ} \mathrm{C}$ and $600{ }^{\circ} \mathrm{C}$. The rock permeability decreases exponentially with an increase in the confining pressure at heating temperatures of less than $100{ }^{\circ} \mathrm{C}$.

2. The permeability of sandstone decreases significantly with the confining pressure increases. When the confining pressure increases to a certain level, the permeability begins to decrease slowly. The permeability of sandstone is larger under the condition of high temperature and low confining pressure.

3. Under high temperatures, sandstone expands when heated and this expansion behavior is mainly caused by the phase transition of quartz. The structural damage resulting from the heating is an important cause for the increase of the permeability of the heated specimens.

\section{ACKNOWLEDGEMENTS}

This research was supported by "the Fundamental Research Funds for the Central Universities" (No. 2017XKZD07) and "the Priority Academic Program Development of Jiangsu Higher Education Institutions".

\section{REFERENCES}

Akinlotan, O.: 2016, Porosity and permeability of the English (Lower Cretaceous) sandstones. Proceedings of the Geologists' Association, 127, 6, 681-690. DOI: 10.1016/j.pgeola.2016.10.006

Bai, L.P., Du, J.G., Liu, W. and Zhou, W.G.: 2002, The experimental studies on electrical conductivities and $\mathrm{P}$-wave velocities of anorthosite at high pressure and high temperature. Acta Seismol. Sin., 15, 6, 667-676. DOI: 10.1007/s11589-002-0091-1

Bauer, S.J. and Johnson, B.: 1979, Effects of slow uniform heating on the physical properties of the westerly and charcoal granites. $20^{\text {th }}$ U.S. Symposium on Rock Mechanics, 4-6 June, 1979, Austin, Texas.

Ding, Q.L., Ju, F., Song, S.B., Yu, Y. and Ma, D.: 2016, An experimental study of fractured sandstone permeability after high-temperature treatment under different confining pressures. J. Nat. Gas Sci. Eng. 34, 55-63.

DOI: $10.1016 /$ j.jngse.2016.06.034

Dutton, S.P., Loucks, R.G. and Day-Stirrat, R.J.: 2012, Impact of regional variation in detrital mineral composition on reservoir quality in deep to ultradeep lower Miocence sandstones, western Gulf of Mexico. Mar. Pet. Geol., 35, 1, 139-153.

DOI: 10.1016/j.marpetgeo.2012.01.006

Egboga, N.U., Mohanty, K.K. and Balhoff, M.T.: 2016, A feasibility study of thermal stimulation in unconventional shale reservoirs. J. Pet. Sci. Eng. 154. DOI: $10.1016 /$ j.petrol.2016.10.041

Gao, H.M.: 2005, Study on law of rock permeability under high-temperature. Liaoning Technical University.

Guo, X., Zou, G., Wang, Y., Wang, Y. and Gao, T.: 2017, Investigation of the temperature effect on rock permeability sensitivity. J. Pet. Sci. Eng., 156. DOI: 10.1016/j.petrol.2017.06.045

Gehne, S. and Benson, P.M.: 2017, Permeability and permeability anisotropy in Crab Orchard sandstone: Experimental insights into spatio-temporal effects. Tectonophysics, 712-713, 589-599.

DOI: $10.1016 /$ j.tecto.2017.06.014

Hetherington, J. and Thambimuthu, K.: 2003, In-Situ Gasification, Enhanced Methane Recovery and $\mathrm{CO}_{2}$. Storage in Deep Coal Seams. Greenhouse Gas Control Technologies, 709-716.

Hajpál, M.: 2002, Changes in sandstone of historical monuments exposed to fire or high temperature. Fire Technol., 38, 4, 373-382. DOI: $10.1023 / \mathrm{A}: 1020174500861$

Hajpál, M. and Török, Á.: 2004, Mineralogical and colour changes of quartz sandstones by heat. Environ. Geol., 46, 3-4, 311-322. DOI: $10.1007 / \mathrm{s} 00254-004-1034-Z$

Jin, Y.U., Chen, S.J., Chen, X., Zhang, Y.Z. and Cai, Y.Y.: 2015, Experimental investigation on mechanical properties and permeability evolution of red sandstone after heat treatments. JZUS-Science A (Applied Physics and Engineering), 16, 9, 749-759.

DOI: 10.1631 jzus.A1400362

Kök, M.V.: 2009, Effect of pressure and particle size on the thermal cracking of light crude oils in sandstone matrix. J. Therm. Anal. Calorim., 97, 2, 403-407. DOI: $10.1007 / \mathrm{s} 10973-008-9637-3$

Kumar, S., Gupta, R.C. and Shrivastava, S.: 2016, Strength, abrasion and permeability studies on cement concrete containing quartz sandstone coarse aggregates. Constr. Build. Mater., 125, 884-891. DOI: 10.1016/j.conbuildmat.2016.08.106

Kumar, S., Sharma, A.K., Sherawat, D., Dutt, M. and Gupta, R.C.: 2017, Technical note on sorption and permeability of concrete containing rubber and quartz sandstone aggregates. Constr. Build. Mater., 145, 311317.

DOI: 10.1016/j.conbuildmat.2017.04.022

Liang, B., Gao, H.M. and Lan, Y.W.: 2005, Theoretical analysis and experimental study on relation between rock permeability and temperature. Chinese Journal of Rock Mechanics and Engineering, 24, 12, 2009-2012, (in Chinese).

Liu, J.R., Qin, J.S. and Wu, X.D.: 2001, Experimental study on the effect of temperature on permeability of rock. J. Univ. Pet. Nat. Sci., 25, 4, 51-53, (in Chinesse). DOI: 10.3321/j.issn:1000-5870.2001.04.015

Popp, T. and Kern, H.: 1993, Thermal dehydration reactions characterized by combined measurements of electrical conductivity and elastic wave velocities. Earth Planet. Sci. Lett., 120, 1-2, 43-57. DOI: 10.1016/0012-821X(93)90022-2

Qian, Y., Jing, H., Haijian, S.U. and Zhu, T.: 2015, Loading rate effect on fracture properties of granite after high temperature. J. China Univ. Min. Tech., 44, 4, 597603.

Ranjith, P.G., Daniel, R.V., Chen, B.J. and Perera, M.S.A.: 2012, Transformation plasticity and the effect of 
temperature on the mechanical behaviour of Hawkesbury sandstone at atmospheric pressure. Eng. Geol., 151, 8, 120-127.

DOI: 10.1016/j.enggeo.2012.09.007

Shafiei, A. and Dusseault, M.B.: 2013, Geomechanics of thermal viscous oil production in sandstones. J. Pet. Sci. Eng., 103, 121-139.

DOI: 10.1016/j.petrol.2013.02.001

Shahverdi, H. and Sohrabi, M.: 2017, A mechanistic model for prediction of three-phase flow in petroleum reservoirs. J. Pet. Sci. Eng., 157. DOI: 10.1016/j.petrol.2017.06.073

Somerton, W.H. and Boozer, G.D.: 1960, Thermal characteristics of porous rocks at elevated temperatures. J. Pet. Tech., 12, 6, 418-422. DOI: $10.2118 / 1372-\mathrm{G}$

Somerton, W.H.: 1961, Additional thermal data for porous rocks-thermal expansion and heat of reaction. SPE J., 1, 4, 249-253. DOI: 10.2118/1613-G

Sun, Q., Zhang, W.Q., Su, T.M. and Zhu, S.Y.: 2016, Variation of wave velocity and porosity of sandstone after high temperature heating. Acta Geophys., 64, 3, 633-648. DOI: 10.1515/acgeo-2016-0021

Takeda, M., Zhang, M., Watanabe, Y. and Taneko, N.: 2009, Applicability of analytical models to single-well permeability tests in deep and hydraulically tight geological formations. J. Hydrol. Eng., 14, 11, 12001207.

DOI: 10.1061/(ASCE)1084-0699(2009)14:11(1200)

Wu, X.D., Liu, J.R. and Qin, J.S.: 2003, Effects of thermal treatment on wave velocity as well as porosity and permeablity of rock. J. Univ. Pet. Nat. Sci., 27, 4, 7072, (in Chinese).
Xu, X.L., Gao, F., Shen, X.L. and Xie, H.P.: 2008, Mechanical characteristics and microcosmic mechanisms of granite under temperature loads. J. China Univ. Min. Tech., 18, 3, 413-417. DOI: 10.1016/S1006-1266(08)60086-3

Yang, S.Q., Xu, P., Li, Y.B. and Huang, Y.H.: 2017, Experimental investigation on triaxial mechanical and permeability behavior of sandstone after exposure to different high temperature treatments. Geothermics, 69, 93-109. DOI: 10.1016/j.geothermics.2017.04.009

You, L.J. and Kang, Y.L.: 2009, Effects of thermal treatment on physical property of tight rock. Prog. Geophys., 24, 5, 1850-1854. DOI:10.3969/j.issn.1004-2903.2009.05.040

Zarichyak, Y.P., Ramazanova, A.E. and Emirov, S.N.: 2013, Contribution of thermal radiation in measurements of thermal conductivity of sandstone. Physics of the Solid State, 55, 12, 2436-2441. DOI: $10.1134 / \mathrm{S} 1063783413120330$

Zhao, H.B., Yin, G.Z. and Chen, L.J.: 2009, Experimental study on effect of temperature on sandstone damage. Chinese J. Rock Mech. Eng., 28, 2784-2788, (in Chinese). 